Article

\title{
Postsecular Plurality in the Middle East: Expanding the Postsecular Approach to a Power Politics of Becoming
}

\author{
Mariano Barbato \\ Center for Religion and Modernity, 48149 Münster, Germany; barbato@uni-muenster.de
}

Received: 4 March 2020; Accepted: 28 March 2020; Published: 1 April 2020

\begin{abstract}
Embedded in a critically adapted version of Jürgen Habermas' postsecular approach, this article analyzes empirically and evaluates normatively the role of religion in the Middle East. Integrating and adapting William Connolly's understanding of political change as power politics of becoming, the argument is that an authoritarian pluralism is evolving that, in contrast to secular nationalism and Political Islam, can be called postsecular insofar as it attempts to integrate more strata of the population into the public discourse, regardless of their religious creed but based on interreligious plurality. The Document on Human Fraternity, signed 2019 in Abu Dhabi, is a prime example of that postsecular trend embedded in power politics. The article concludes that the turmoil of the Arab Spring did not pave the way for democracy but for authoritarian and partisan versions of a postsecular public that try to accommodate the plurality of the Middle East.
\end{abstract}

Keywords: postsecular society; Middle East; politics of becoming; desecularization; Jürgen Habermas; William Connolly; Arab Spring; Document on Human Fraternity; Muslim Council of Elders; Pope Francis

\section{Introduction}

The claim that the Middle East could be described as postsecular seems to be counterintuitive. An alleged lack of secularization, a number of deadly conflicts concerning religion, and authoritarian restrictions on public discourse seem to foreclose any meaningful application of the concept to the region. My claim is that an authoritarian version of interreligious pluralism became the postsecular alternative to pan-Arabic secularism and Political Islam-Islamism and Post-Islamism.

The postsecular approach is understood as an analytical tool to observe but also as a normative framework to evaluate an expanding integration of diverse social and religious strata into the public discourse without providing a comprehensive, homogenizing doctrine. Based on these analytical and normative considerations, the Middle East can be called postsecular, if all kinds of religious and non-religious citizens can participate equally in public and politics, as long as they do not intend to reshape society and state on the basis of a homogenizing political creed of their faith. While this normative benchmark cannot be detected in a full sense, an authoritarian move in that direction can be observed in countries such as Egypt or the UAE, organized and connected by transnational elites. The most impressive step within this authoritarian postsecularism was achieved in Abu Dhabi in 2019 when the Document on Human Fraternity (Francis and al-Tayyib 2019) was signed by Pope Francis and Grand Imam Ahmad al-Tayeb. This article's second part will elaborate on these examples to show how the expansion of the postsecular approach to authoritarian power politics of becoming could help us to understand the Middle East.

The argument is embedded in the broad and ongoing critical debate on secularism and secularization theory that has been pioneered, among others, by such diverse thinkers as Talal Assad (Asad 2003), 
Jose Casanova (Casanova 1994), Charles Taylor (Taylor 2007), or Peter Berger (Berger 1999), who allowed, broadly speaking, in their critical examination of the historical development of secularism and secularization theory, a fresh look on alternative frameworks, global trends of desecularization, and the vitality of religion in public.

Methodologically, this article draws on two thinkers within these debates: Jürgen Habermas (Habermas 2006, 2008) and William Connolly (Connolly 1999). Jürgen Habermas has introduced a sophisticated and widely discussed concept of a postsecular society that frames the theoretical background of this study. As it informs, in an adapted version, the basic ideas of my argument, a short reminder of Habermas' concept and its critical discussion opens up the discussion of the first part. This opening serves also as a starting point for a historical analysis that draws attention to the emergence of a public sphere through transnational religious intellectuals within the power politics of authoritarian rulers.

On this crucial point, William Connolly's term "politics of becoming" (Connolly 1999, p. 51) will support my argument based on a critical reading of Habermas. As will be elaborated, Connolly has a normative idea of change and transformation, which he calls "politics of becoming" and which includes a vision of society of deep differences that can nevertheless develop strong social fabrics. However, Connolly is well aware that such a transformation does not often go smoothly and rarely manages to integrate the consensual participation of everyone. Expanding this concept, one could speak about power politics of becoming.

\section{Deep Postsecularism and the Politics of Becoming}

Jürgen Habermas began to speak about a postsecular society only weeks after 9/11 (Habermas 2006, pp. 101-15). Instead of nourishing the secular-religious divide by lumping all kinds of believers together, the philosopher and social scientist presented another option: dividing self-reflexive postsecularists, religious, and agnostics from ideologists who insist on their religious or secularist world views. One of the most important encounters in which he discussed this approach was the debate with Joseph Cardinal Ratzinger, who became shortly afterwards Pope Benedict XVI (Habermas et al. 2006). Habermas discussed and developed his approach in various contexts and debates over a period of almost two decades (Butler et al. 2011; Calhoun et al. 2013; Habermas 2008, 2010). William Connolly conceptualized his postsecular approach of deep pluralism and politics of becoming before Habermas (Barbato and Kratochwil 2009; Connolly 1999; Kaltsas 2019). Here is not the place to elaborate the whole debate, but a recall of the basic components and a brief look on the latest developments seem to be in order to discuss the adaption to the situation in the Middle East.

\subsection{Habermas' Postsecular Approach: Basic Ideas and Current Developments}

Basically, Habermas' argument is threefold. The first point is a sociological analysis: at least for the time being, secularization theory is wrong. There are many modern, well-educated people who still believe in God and accept various kinds of sophisticated, religiously informed doctrines. Note that Habermas still trusts analysts who give evidence that secularization theory might prevail in the long run. However, he also acknowledges that religious people are more resistant in upholding moral arguing under the pressure of a capitalist modernity, which causes social pathologies elsewhere. The second issue is a problem of political theory: given the, at least current, stable existence of religious strata and their moral convictions, a ban of religious arguments from the public sphere is not viable within an inclusivist liberal concept of the public, which is in dire need of support against social pathologies. Rigid secularism as a political project is therefore morally and politically wrong. However, this verdict against secularism is a limited one. Habermas still believes that religious language is less rational than secular language. Rational arguments are the corner stone of every public deliberation, and only they lead to legitimate politically binding and juridically enforceable decisions. Thus, religious claims can be made in public, but as soon as the deliberation process enters political or juridical institutions, which are entitled to make binding and enforceable decisions, religious vernaculars have to be translated into 
a secular language. The third insight is a philosophical claim: religious language is richer than secular discourse. The translation process, which is necessary for a political decision, is also an enrichment for the debate. Secular reasoning freed thoughts from their religious shelf. Sometimes this process destroyed semantics worth being kept or did not succeed in translating all of the valuable meaning that was contained by the religious concept (Barbato and Kratochwil 2009; Calhoun et al. 2013; Habermas 2006; Habermas et al. 2006, pp. 101-15).

Within the debates and developments of Habermas' approach, a few aspects need to be discussed in some more detail with respect to the question of applying the concept to the Middle East: even in his latest work, Habermas trusted Pippa Norris' and Ronald Inglehart's (Norris and Inglehart 2011) empirically ill-proven claim that better-off societies secularize, while poorer and more fertile strata of the world population are more religious (Habermas 2019, p. 84). Progress, according to this view, might thus back secularization theory in the long run. That claim stands historically in stark contrast to the experience of European modernity, in which mass deprivation led to atheist labor movements and the poor peasants of Russia backing Lenin's revolution (Chadwick 1990). Looking at the modern Middle East of the 21st century, in particular at the Arab peninsula with a domestic product far beyond global average, the thesis should be considered false. The so-called oil sheiks are not only fabulously rich, they are able to compete in setting standards in architecture, infrastructure, technology, and sustainability. Nevertheless, there are no indications that these modernization processes will have an impact on religiosity, as would be expected by secularization theory. While there is stiff competition among the various interpretations of Islam, with Qatar on the side of the Muslim Brotherhood and the UAE on the side of authoritarian pluralism, secularist tendencies do not rank high within these societies. Incoming poor migrant labor and the well-off nationals of the Gulf emirates are obviously divided by class, often in their creed, but less in their degree of religiosity. We do not see any history repeating of Marxist working class or Enlightenment bourgeois secularization as demonstrated in early modern Europe. The thesis of rich and secular vs. poor and religious should be considered false due to the example of the Middle East.

Habermas restricts his notion of a postsecular society to Western countries (Habermas 2008). For him, only those societies went through a full modernization process that experienced a balanced combination of religious decline and enlightened religious resistance as a precondition for the postsecular arrangement between secular and religious citizens. Here is not the place to make a global comparison, but it is safe to say that two hundred years of secularization that started initially with Napoleon's Egyptian campaign (1798-1801) and became a genuine Turkish and Arabic project after the end of the Ottoman Empire had some effects in the Middle East. Processes of secularization can be effective in political, public, and private realms. The decline of religion does not have to be sharp or close to zero to observe reversing trends to secularization, which Peter Berger labeled as desecularization (Berger 1999). It is of course open to debate whether secularization will triumph in the long run in the Middle East. It is also possible that religious resistance, beginning with the assignation of French General Kléber by Suleiman al-Halabi (1800), will prevail either because Islam is, for good or bad, immune to full-fledge secularization processes or because Political Islam has better answers to the challenges of modernization. In any case, the Middle East is not just a landscape or a geopolitical region but a public space in which transnational elites and masses discuss their joined and differentiating experiences and judgements as they go through processes of secularization and desecularization.

A brief look at the history of the Middle East might be in order to sketch that development. The pan-Arabism of Gamal Abdel Nasser's Egypt or the Ba'ath Party in Syria and Iraq, the White Revolution of Sha Reza Pachlevi in Iran, the postcolonial socialism of the Algerian Front de Libération Nationale, the republican and socialist states of Yemen, and Kemal Atatürk's laicism, as well as the Israeli-Palestinian conflict between Zionists and the PLO (Palestine Liberation Organization) were secular enough to classify the Iranian Revolution, the rise of the Muslim Brotherhood, the emergence of the Islamic State, the electoral victory of Recep Tayyip Erdoğan in Turkey and the following settlement of his rule, the Pyrrhus victory of the Islamic Salvation Front and the following Civil War in Algeria, 
the mainly Shia-Sunni split in Yemen's current war, and the increasing role of religious nationalism in the State of Israel and in Hamas' rule in Gaza as clear indicators of desecularization. The rise of Political Islam, broadly understood as a comprehensive political doctrine based on Islam, after the failures of secular nationalism varies but is evident (Cesari 2014; Tamimi and Esposito 2000).

Political Islam challenged not only secularist nationalists but also more traditional monarchies, such as Morocco, Jordan, Saudi-Arabia, and the Gulf Emirates. Those dynasties that were stable enough to survive the secularist and nationalist challenge were able to modernize without compromising their monarchical rule. The demands of democratic participation pressured monarchies with populous nations, such as Morocco or Jordan, to integrate Political Islam within their political system (Brown and Hamzawy 2010). Since the Grand Mosque Seizure of 1979, the Saudi dynasty had to prove the legitimacy of their rule to Wahhabi scholars and fostered Salafism in the region and globally. The home-grown terrorism of Osama Bin Laden worsened the situation (Hegghammer 2010). The Gulf Emirates, such as the UAE or Qatar, whose population is composed mainly of migrant workers, had less internal pressure but saw the need to project their power into the region to maintain the rule of their dynasties at home. The opposing decisions of the UAE and Qatar after the Arab Spring is one of the major cleavages in today's Middle East (Davidson 2019; Kourgiotis 2020). Thus, it is safe to say that the Middle East saw processes of secularization and desecularization that resulted in a political landscape of deep and conflictual plurality concerning legitimate relationships of religion and politics.

However, the conflictual plurality is not restricted to a split within the Sunni community concerning the reaction to democratization, to Political Islam in general and the Muslim Brotherhood in particular, or to Iran and uprising Shia communities. There are many other cleavages vibrant in the region. Still dominant and spilling over into other areas and issues is the Israel-Palestine conflict. Last, but not least, the diverse Christian communities, ranging from the oldest Christian traditions, speaking the Aramaic language of Jesus to the Christian migrant workers from Asia and Africa, particularly in the Gulf Emirates, are part and parcel of the plurality of the Middle East (Stetter and Nabo 2020). Christian thinkers and politicians, such as Constantin K. Zurayk, held high-ranking positions in the pan-Arabic movement. They embraced secularism as a way to avoid Muslim dominance and saw Arabic nationalism as an opportunity to leave the inferior status they had in the millet system of the Ottoman Empire and become full citizens of the postcolonial nation states (Sabra 2006). Secular nationalism was, however, a troublesome solution for minorities as well (Mahmood 2016). While the nationalist Young Turks and Kemal Atatürk based their nation building project on religious and ethnic cleansing and homogenization in favor of a Sunni nation of Turks but chose a rigid laicism that imposed state control on religion, pan-Arabism was much more open to pluralism, and its secularism was much less rigid. It provided a political identity to which all religious fractions of society were supposed to belong. The terror reign of the Islamic state against various non-Sunni communities in Syria and Iraq, based on a kind of Sunni nation-building (Barbato et al. 2016), as well as the all-out campaign of the Alawite regime of Assad against the majority of the Sunni citizens of Syria, revealed the plurality of religious and ethnic belongings that secular pan-Arabism and the Ba'ath Parties of Syria and Iraq once tried to integrate, partly at the expense of the Sunni majority, in Iraq, particularly at the expense of Shias and Kurds. Already this very brief sketch of the history of the Middle East challenges the orientalist notion that only the West experienced secularization and desecularization deep enough to become ready for postsecular developments.

A postsecular society emerges when the religious cleavage loses its dominance due to a pluralist arrangement open to both religious and secular arguments. The debate about weaker or stronger versions of postsecularism was united in ruling out authoritarian claims but restricted itself to the rational deliberation of religious and non-religious arguments (Butler et al. 2011; Cooke 2007). Arguing for integrating authoritarian rule into the postsecular approach heavily compromises this normative demand. The argument here is not that authoritarian rule can be part of the postsecular ideal. Both the strong and the weak reading of the postsecular approach (Barbato and Kratochwil 2009; Chambers 2007) depend on the common ground that rational deliberation in contrast to authoritarian decision is the 
decisive point for the normative concept. The argument here is rather that postsecular developments can be observed even though they are part of a broader picture that is shaped by authoritarian rule and power politics. As the debate of Habermas' deliberative approach in international relations has shown, deliberations are islands embedded in strategic actions of power politics (Deitelhoff 2009). These insights have to be integrated in the debate about a postsecular society, particularly in international relations (Mavelli and Petito 2014).

Habermas' latest discussion of the entanglements of religion and politics and the historical emergence of a public sphere in Europe are illuminative for the argument here. Based on Rosenstock-Huessy's claim of a papal revolution in the 11th century (Rosenstock-Huessy 2013, pp. 516-61) and Bergman's discussion of this thesis with respect to the emergence of the rule of law based on canonical law (Berman 1995), Habermas argued that the popes' claim of supremacy over politics based on doctrine and law paved the way for accountability and delegitimized the self-understanding of emperor and kings that their bare will was already sanctioned by God as lawful. The clerical elite of the popes were able to push through remarkable parts of the papal program. In the entanglements of religious and political elites based on the doctrine of an ideological superiority of the clerics over the might of the warriors, an open public and the rule of law could emerge (Habermas 2019, pp. 637-75).

Obviously, the papacy or an equally unified and unifying religious actor does not play a comparable role in the Middle East. However, the emergence of rule of law, a critical pluralist public, and a tamed and accountable political power might not need unified religious balancing but only a pooled and pluralist religious counterpart. The decisive point for the effect of the papal revolution is less the institutionalized power than the claim to represent ideological supremacy without monopolizing political power. The popes tried to be influential and insisted on the entanglements of politics and religion, but, apart from the status of a prince in the Papal States, the popes never attempted to become political rulers of the space they tried to dominate doctrinally. This concomitance of a claim of ideological supremacy on the one hand and political abstinence and neutrality in favor of the rule of law and doctrine on the other hand opened up the space for a public sphere. It is well known that the history of the papacy has its dark sides of corruption and hubris. However, in some respect that is a sign for hope rather than for despair. It does not take constant saintly behavior on the side of religious actors and their institutions to trigger the emergence of the rule of law, a critical public, and the taming of political power.

Transferring these insights to the Middle East brings an essential argument into focus: the disentanglements of religion and politics, so often imposed on the Middle East and simultaneously lamented as impossible, are not necessary for normatively viable progress, but a powerful interreligious coalition of religious actors that claim public authority for the sake of the rule of law and a critical public but do not aim for revolutionary regime change in order to take political office by themselves is crucial. The claim here is not that a postsecular Middle East in this ideal sense is in the offing. However, the Arab Spring already showed opportunities in that direction, and most recently, the Document on Human Fraternity, signed by Grand Imam Ahmad al-Tayeb and Pope Francis, laid the programmatic ground for such an endeavor. The postsecular concept has to be tailored to detect these trends.

\subsection{Connolly's Postsecular Approach: Deep Pluralism and Politics of Becoming}

Two decades ago, William Connolly had already begun to criticize the rigid ideology of secularism because it does not provide, quite in contrast to its self-understanding, a common ground for everyone but excludes as a partisan project most of the religious members of the citizenry. While secularism offers a foundational ideology to integrate various world views, Connolly pleaded for a deep pluralism in order to find pragmatic compromises, not foundational consensus (Connolly 1999). The term of deep pluralism or negotiated pluralism invites us to trust in a society that differs fundamentally in various aspects of its creeds but is nevertheless able to find bridges and connect networks that construct viable social fabrics based on mutual respect, an open public, and the rule of law. However, such an endeavor comes with a prize for those who profit from the frictions of today. Connolly's term for such 
costly transformations is politics of becoming. Change is costly for those benefiting from established arrangements. Or, in Connolly's own words,

"The most complex ethical issues arise in those contexts where suffering is intense and its visitation upon some is bound up with securing the self-confidence, wholeness, transcendence, or cultural merit of others. That is, the most intense, intractable cases of suffering are political in character. They often revolve around what I call the politics of becoming" (Connolly 1999, p. 51).

The decisive question for the politics of becoming is the attitude of those who benefit from current arrangements. Do they trust in the promises of the transformation because they also see a role for themselves in the new arrangements, or not? A positive or a negative answer decides about fierce resistance or smooth transitions (Connolly 1999, p. 58).

Connolly's politics of becoming are open to the question of power. His approach has not enough trust in the pacifying force of reason to avoid the issue of exclusion by marginalizing the excluded strata as irrational. However, the idea of politics of becoming is framed as an emancipating project that should replace authoritarian exclusion instead of exchanging one authoritarian rule for another.

Power politics of becoming goes one step further. Again, the argument is not that authoritarian rule can be normatively justified but that an analysis of normatively meaningful postsecular developments is not to be disgraced because those developments are embedded in power politics or fostered and supported by actors who also intend to protect, stabilize, and legitimize their authoritarian rule. An expansion of the postsecular approach to the power politics of becoming is suitable for a fine-grained analysis without losing the capacity for a normatively sensitive evaluation.

\section{Postsecular Power Politics of Becoming on the Ground: Arab Spring and the Abu Dhabi Document on Human Fraternity}

From a normative as well as from an empirical perspective, the Arab Spring ended in a disaster. Only the forerunner Tunisia was successful in establishing a, at least, "flawed" democracy (The Economist 2020). While Algeria's experience of its civil war made it immune to any contagion effect, the thawing wind brought the Arab Spring eastwards. The authoritarian regime faltered and toppled, but democracy was not established. Whether the old dictators were killed, exiled, discharged, or kept in office, Libya, Yemen, and Syria were stuck in endless war, while Egypt returned to an authoritarian rule under a former general. Would the Middle East be a better place if the Arab Spring never happened? Looking at the death toll and the rise of the Islamic State, there is great temptation to denounce the uprising. However, the failure to establish a new order does not necessarily delegitimize the will of the people to resist corruption and oppression. Perhaps this experience of a postsecular revolution (Barbato 2012) might still form the basis for an emerging new order of the Middle East.

\subsection{The Postsecular Impact of the Arab Spring}

Postsecular revolution can be defined as taking place in order to end secularist, religious, and mixed regimes, which legitimize their authoritarian rules by the need to freeze the cleavage between more secular and more religious citizens or by protecting or excluding minorities defined by their belonging to a religious community or a religious ideology. A successful postsecular revolution can be defined by a new arrangement that cherishes various forms of religious heritage of the society without establishing an exclusivist creed to which all citizens have to conform, be it a civil religion, a traditional faith, or a comprehensive religious doctrine. The deep pluralism of a postsecular society takes differences seriously without fearing them. Postsecular societies trust that a politics of becoming that accepts these differences but delegitimizes differences of status and class, including the injustices of a corrupt regime, is better off (Barbato 2012, pp. 1081-83). More religious and more secular strata of the population, whether they organize their differences in parties or not, no longer understand this cleavage as a cause for civil war because an electoral victory of the other side is unacceptable. A losers' consent (Anderson 2007) is possible as the winning party is not trying to marginalize the interests and the existence of the defeated, and the next turn to the ballots could have an equally accepted different result. Only those extremists who 
do not accept these rules of the democratic game are marginalized and, if necessary, persecuted in due process of law. This is the ideal version. An extension to postsecular power politics of becoming can also see some progress within less ideal circumstances. Egypt can be understood as an example of this.

The broad alliance that protested against the elected Egyptian president Mohammed Morsi and the new Islamist but electorally approved constitution and later backed first al-Sisi's coup and then his election as president denied the losers' consent due to the game-changing character of the new rulers' constitution. Despite the suppression of the Muslim Brotherhood and others, which violated basic standards of human rights on a massive scale, al-Sisi could be understood as still being on a postsecular path, as he sticks to the view that he once stated in a term paper: "The moderate view is that there is a place of Islamic belief. [ ... ] A common religious understanding among all ethnicities and cultures must exist and there must be consideration given to non-Islamic belief"' (El Sisi 2006, p. 11).

Based on these views, al-Sisi became the first Egyptian president who attended a Coptic Christmas Mass in 2015 (Kirkpatrick and Merna 2015). After the murderous attack on a church in 2016, he asked the parliament to lift the legislative ban on major new church buildings and commissioned the construction of the largest cathedral in the Middle East for the new administrative capital of Egypt. In 2019, it was inaugurated. Al-Sisi, a pious Sunni, was able to gain support from Sheik Ahmad al-Tayeb, Grand Imam of al-Azhar and a leading authority in Sunni Islam, who, similar to al-Sisi, visited the new cathedral and supported the right of Christians and Jews to have their buildings of worship protected (Reuters 2019).

Thus, the regime is still authoritarian and exclusivist in terms of marginalizing any kind of Political Islam or other dissenters by authoritarian means. However, the integration effort towards different strata of the population and the shift from secularist nationalism to an interreligious nationalism, bringing together Sunni Muslim and Copts, is a postsecular step forward. It seems to be feasible because al-Sisi, who was once brought into office as minister of defense by Morsi due to his piety, and the coalition that backed initially the military coup to support the continuity of the Arab Spring revolution were united on the common postsecular ground that religion should play a role in public and politics but not as a exclusivist comprehensive doctrine of Political Islam. Given the strength of Political Islam and the decline of secular pan-Arabism, a balanced postsecular society in the full Habermasian sense is not in the offing. However, the current authoritarian rule engages in postsecular power politics of becoming.

\subsection{The Abu Dhabi Delcaration of Human Fraternity}

Less than a month after the inauguration of the new cathedral, Al-Tayyeb met the Roman Pontiff and head of the Catholic Church, Pope Francis, in Abu Dhabi. The two religious authorities signed a declaration called the "Document on Human Fraternity for World Peace and Living Together" (Francis and al-Tayyib 2019). The document was framed as a global invitation of the two leaders to embrace the challenges of plurality in order to promote peace and fraternity among all people. The document presents an ambitious list of objectives, including hotly contested issues within the religious communities, such as religious freedom and equal rights for women. The global echo was significant. The long-standing papal efforts in this respect were honored (Barbato 2019; Gagliarducci 2019) but also sharply criticized, particularly by some inside the Catholic Church, as the document seemed to embrace religious pluralism, favored by some Church members but rejected by the magisterium of the Church. However, a closer look reveals that the alleged pluralist theology behind the document hints less to liberal Catholics than to Orthodox Quran teaching (Körner SJ 2019, pp. 615-17). In the driving seat of the document was not the papacy but the Muslim side, more specifically the Muslim Council of Elders, the Forum for Peace in Muslim Societies, and their Abu Dhabi host.

UAE strongman, crown prince Mohammed bin Zayed Al Nahyan, is the patron of the Muslim Council of Elders that consists of a board of senior scholars and former politicians. Al-Tayeb is the president of the council. An important member of the board and vice president is Abdallah Bin Bayyah, 
a former Mauritanian politician and Saudi Arabia-affiliated scholar, who is the founder and president of the Forum for Peace in Muslim Societies (Muslim Council of Elders 2020).

Abdallah Bin Bayyah's activities and affiliation shed a light on the controversies behind the declaration and what is at stake for the Middle East in a postsecular society that transcends secularist nationalism but is also post-Islamist (al-Azami 2019). Until 2014, he was vice president of the International Union of Muslim Scholars and close ally of the then-president Yusuf al-Qaradawi, an eminent scholar and public intellectual affiliated with the Muslim Brotherhood. The Egyptian is exiled in Doha, Qatar, where he has a prominent program on Al Jazeera.

During the Arab Spring and the following turmoil, Middle East scholars and rulers had to make some tough decisions. Due to the turmoil, the old alliances of scholars and rulers became unstable and fluid. Alliances had to be reaffirmed or reshuffled. The transnational public of the Middle East engaged in heavy controversies regarding how to adjust to the new situation. Muslim scholars, such as Yusuf al-Qaradawi and Abdallah Bin Bayyah, opted for different political and public alliances. However, not only scholars, but also rulers had to make decisions. Qatar opted for Political Islam and the open support of the Muslim Brotherhood. Abdallah Bin Bayyah broke with his Muslim Brotherhood partners and old friend Yusuf al-Qaradawi, who called for jihad in Egypt and Syria. Bayyah founded his own association, the Forum for Peace in Muslim Societies. It is based in Abu Dhabi under the patronage of the dynasty that opted for a stiff fight against the Muslim Brotherhood and its vision of an Islamic democracy. Bayyah, who is also a co-moderator of the World Council of Religions for Peace, is well-connected to the global movements of interreligious relationships (World Council|Religions for Peace International 2020).

One of the first new initiatives of Bayyah was the Marrakesh Declaration in 2016 that called for the rights and protection of religious minorities under Muslim rule, particularly in reaction to the terror of the Islamic State (Marrakesh Declaration 2016). One of the most important points was that devout Muslim scholars, not secularists, spoke of citizenship that had to include non-Muslims (Körner SJ 2019, p. 613).

Interreligious dialogue and an interreligious inclusive citizenship became an option for moderate Muslim scholars who were not willing to opt for jihad and Political Islam. This kind of interreligious pluralism became the postsecular alternative to pan-Arabic secularism and Political Islam.

Coming back to the question of the Muslim-papal relationship and the Abu Dhabi declaration, the real news with respect to the papacy is that renowned Muslims scholars and elder statesmen backed by powerful rulers were interested in joining forces with the papacy in a public diplomacy event to promote peace in the Middle East and strengthen Muslim identity as a peaceful nation, internally as well as externally. Even the Qatari state-funded broadcaster Al Jazeera was ready to pay tribute to the papal visit but also pointed at the human suffering caused by the war in Yemen, which was supported by the UAE (Al-Jazeera 2019). The interreligious outreach also seems to be, from a Qatar perspective, not a legitimate target to be criticized, even though the public papal mass on the sacred soil of the Arab peninsula could have been used as a reason for an outcry (Wood 2019). Nothing in this respect happened, however.

To understand the rationale behind the Abu Dhabi declaration, it is worth quoting the presented self-understanding of the council from the council's website:

"The Muslim Council of Elders is an independent international organization that was established in Ramadan 21, 1435 Hijri (18 July 2014) to promote peace in the Muslim communities. The Council unites Muslim scholars, experts and dignitaries who are known for their wisdom, sense of justice, independence and moderateness. They will work together to promote peace, to discourage infighting and to address the sources of conflict, divisiveness and fragmentation in Muslim communities. Based in the United Arab Emirates' capital, Abu Dhabi, the Council is the first institutional body that aims to bring the Islamic nation together by extinguishing the fire that threatens Islam's humanitarian values and principles of tolerance, and putting an end to the sectarianism and violence that have plagued the Muslim world for decades." (Muslim Council of Elders 2020) 
A council that focuses on inner Muslim unity and peace chooses an interreligious outreach in order to achieve its objective. The Document on Human Fraternity could, hence, be labeled as the manifest of a postsecular Middle East.

However, the objectives are in line with the UAE policy of founding a bulwark against Iranian hegemony and Political Islam. Scholars and rulers formed a broad coalition in order to frame and legitimize their policy and action on a new basis that embraces deep plurality. A pluralist and interreligious society backed by authoritarian rule in contrast to a Sunni majority democracy voting for Political Islam became a viable option for scholars and rulers alike. The entanglements of rulers and scholars are still too close to detect here the emergence of a critical public, such as the one Habermas attested to in the Papal Revolution of 1075. Nevertheless, inviting the pope, spanning an international and interreligious network, and integrating these efforts into a long-standing framework such as Religions for Peace are major steps towards an independent transnational public beyond authoritarian control.

Within half a year after the declaration, the papacy and the Council of Elders founded an interreligious organization, the Higher Committee of Human Fraternity, which also has a Jewish member. The committee's first major project is the erection of an interfaith complex in Abu Dhabi, called the Abrahamic Family House. The majestic compound will assemble a mosque, a church, and a synagogue and connect them below the surface with a conference center (The Higher Committee of Human Fraternity 2020). The postsecular impact coming from the Middle Eastern power politics of the becoming should not be underestimated.

\section{Conclusions}

Desecularization happens when secularist approaches lose their function of legitimizing power or no longer manage to exclude or restrict religion from or in the public sphere and political institutions. While Political Islam promised to integrate either the pious Sunni or Shia masses, which were excluded or whose participation was restricted under a secular regime, secular nationalism pretended to be strong on integrating diverse religious communities. The rationale of more or less secular interreligious coalitions of minorities, such as the Alawite dominated regime of Syria, is still to prevent the loss of vested rights to a religious, here Sunni, majority.

A postsecular politics of becoming overcomes this dichotomy without suspending the deep pluralism of the region. The plurality of the Middle East is becoming increasingly postsecular as public and political arrangements emergence that integrate more religious communities into public life and political participation without denying pious strata of the population participation on the basis of their creed, as long as they abstain from homogenizing politics as part of their politics of becoming. The traditionalist coalition, spearheaded by the UAE, Egypt, and the Muslim Council of Elders who signed the Document of Human Fraternity, seems to present a promising approach of a postsecular Middle East in that respect. However, the project is certainly embedded within a restrictive and authoritarian version of power politics of becoming.

Funding: This research was funded by the German Research Foundation/Deutsche Forschungsgemeinschaft (DFG), grant number: 426657443.

Acknowledgments: I thank the three anonymous reviewers for their very helpful comments.

Conflicts of Interest: The author declares no conflict of interest.

\section{References}

al-Azami, Usaama. 2019. 'Abdullāh Bin Bayyah and the Arab Revolutions: Counter-revolutionary Neo-traditionalism's Ideological Struggle against Islamism. The Muslim World 109: 343-61. [CrossRef]

Al-Jazeera. 2019. Pope Francis Holds First Papal Mass in Abu Dhabi. Doha: Al-Jazeera.

Anderson, Christopher. 2007. Losers' Consent: Elections and Democratic Legitimacy. Oxford: Oxford University Press. Asad, Talal. 2003. Formations of the Secular: Christianity, Islam, Modernity. Stanford: Stanford University Press. 
Barbato, Mariano. 2012. Postsecular Revolution: Religion After the End of History. Review of International Studies 38: 1079-97. [CrossRef]

Barbato, Mariano, Sinja Hantscher, and Markus Lederer. 2016. Imagining Jihad. Global Affairs 2: 419-29. [CrossRef]

Barbato, Mariano, and Friedrich Kratochwil. 2009. Towards a Post-Secular Political Order? European Political Science Review 1: 317-40. [CrossRef]

Barbato, Mariano P. 2019. Papal Dialogue with Islam: A Long Way to Abu Dhabi, a Long Way to Peace. Bristol: E-International Relations.

Berger, Peter L., ed. 1999. The Desecularization of the World: Resurgent Religion and World Politics. Washington, DC: Eerdmans.

Berman, Harold Joseph. 1995. Law and Revolution I. The Formation of the Western Legal Tradition. Cambridge: Harvard University Press.

Brown, Nathan J., and Amr Hamzawy. 2010. Between Religion and Politics. Washington, DC: Carnegie Endowment for International Peace.

Butler, Judith, Jürgen Habermas, and Charles Taylor. 2011. The Power of Religion in the Public Sphere. Edited by Eduardo Mendieta and Jonathan VanAntwerpen. New York: Columbia University Press.

Calhoun, Craig J., Eduardo Mendieta, and Jonathan Van Antwerpen, eds. 2013. Habermas and Religion. Cambridge: Polity Press.

Casanova, José. 1994. Public Religions in the Modern World. Chicago: University of Chicago Press.

Cesari, Jocelyne. 2014. The Awakening of Muslim Democracy: Religion, Modernity, and the State. New York: Cambridge University Press.

Chadwick, Owen. 1990. The Secularization of the European Mind in the Nineteenth Century. Cambridge: Cambridge University Press.

Chambers, Simone. 2007. How Religion Speaks to the Agnostic: Habermas on the Persistent Value of Religion. Constellations 14: 210-23. [CrossRef]

Connolly, William E. 1999. Why I Am Not a Secularist. Minneapolis: University of Minnesota Press.

Cooke, Maeve. 2007. A Secular State for a Postsecular Society? Postmetaphysical Political Theory and the Place of Religion. Constellations 14: 224-38. [CrossRef]

Davidson, Christopher M. 2019. The UAE, Qatar, and the Question of Political Islam. In Divided Gulf: Contemporary Gulf Studies. Edited by Andreas Krieg. London: Palgrave Macmillan, pp. 71-90.

Deitelhoff, Nicole. 2009. The Discursive Process of Legalization: Charting Islands of Persuasion in the ICC Case. International Organization 63: 33-65. [CrossRef]

El Sisi, Abdel Fattah Said. 2006. Democracy in the Middle East. Carlisle, PA, USA: U.S. Army War College.

Francis, and Ahmad al-Tayyib. 2019. Document on 'Human Fraternity for World Peace and Living Together'. Available online: http://www.vatican.va/content/francesco/en/travels/2019/outside/documents/ papa-francesco_20190204_documento-fratellanza-umana.html (accessed on 28 February 2020).

Gagliarducci, Andrea. 2019. Here Is Why Pope Francis' Trip to the UAE Is Benedict XVI's Vindication. Monday Vatican. Available online: http://www.mondayvatican.com/vatican/here-is-why-pope-francis-trip-to-theuae-is-benedict-xvis-vindication (accessed on 11 February 2019).

Habermas, Jürgen. 2006. The Future of Human Nature. Reprinted. Cambridge: Polity Press.

Habermas, Jürgen. 2008. Notes on Post-Secular Society. New Perspectives Quarterly 25: 17-29. [CrossRef]

Habermas, Jürgen. 2010. An Awareness of What Is Missing: Faith and Reason in a Post-Secular Age. Cambridge and Malden: Polity.

Habermas, Jürgen. 2019. Auch eine Geschichte der Philosophie: Band 1: Die okzidentale Konstellation von Glauben und Wissen. Berlin: Suhrkamp.

Habermas, Jürgen, Pope Benedict XVI, and Florian Schuller. 2006. The Dialectics of Secularization: On Reason and Religion. San Francisco: Ignatius Press.

Hegghammer, Thomas. 2010. Jihad in Saudi Arabia: Violence and Pan-Islamism since 1979. Cambridge and New York: Cambridge University Press.

Kaltsas, Spyridon. 2019. Habermas, Taylor, and Connolly on Secularism, Pluralism, and the Post-Secular Public Sphere. Religions 10: 460. [CrossRef]

Kirkpatrick, David D., and Thomas Merna. 2015. Egyptian Leader Visits Coptic Christmas Eve Service. New York Times, June 7.

Körner SJ, Felix. 2019. Die Geschwisterlichkeit Aller Menschen. Theologisch-Islamwissenschaftlicher Kommentar Zum Dokument von Abu Dhabi. Stimmen der Zeit 2019: 605-18. 
Kourgiotis, Panos. 2020. 'Moderate Islam' Made in the United Arab Emirates: Public Diplomacy and the Politics of Containment. Religions 11: 43. [CrossRef]

Mahmood, Saba. 2016. Religious Difference in a Secular Age: A Minority Report. Princeton: Princeton University Press. Marrakesh Declaration. 2016. Available online: http://www.marrakeshdeclaration.org/ (accessed on 25 February 2020). Mavelli, Luca, and Fabio Petito, eds. 2014. Towards a Postsecular International Politics: New Forms of Vommunity, Identity, and Power. New York: Palgrave Macmillan.

Muslim Council of Elders. 2020. Available online: https://www.muslim-elders.com/en (accessed on 25 February 2020).

Norris, Pippa, and Ronald Inglehart. 2011. Sacred and Secular: Religion and Politics Worldwide, 2nd ed. Cambridge: Cambridge University Press.

Reuters. 2019. Egypt's Sisi Opens Mega-Mosque and Middle East's Largest Cathedral in New Capital. Available online: https://www.reuters.com/article/us-egypt-religion/egypts-sisi-opens-mega-mosque-and-middleeasts-largest-cathedral-in-new-capital-idUSKCN1P00L9 (accessed on 7 January 2019).

Rosenstock-Huessy, Eugen. 2013. Out of Revolution: Autobiography of Western Man. Eugene: Wipf and Stock Publishers.

Sabra, George. 2006. Two Ways of Being a Christian in the Muslim Context of the Middle East. Islam and Christian-Muslim Relations 17: 43-53. [CrossRef]

Stetter, Stephan, and Mitra Moussa Nabo, eds. 2020. Middle East Christianiy: Local Practices, World Societal Entanglements. Cham: Palgrave Pivot.

Tamimi, Azzam, and John L. Esposito, eds. 2000. Islam and Secularism in the Middle East. New York: New York University Press.

Taylor, Charles. 2007. A Secular Age. Cambridge: Belknap Press of Harvard University Press.

The Economist. 2020. EIU Democracy Index 2019—World Democracy Report. Available online: https://www.eiu. com/topic/democracy-index (accessed on 28 February 2020).

The Higher Committee of Human Fraternity. 2020. Abrahamic Family House. For Human Fraternity. Available online: https://www.forhumanfraternity.org (accessed on 28 February 2020).

Wood, Graeme. 2019. The Vatican and the Gulf Have a Common Enemy. The Atlantic, March 1.

World Council|Religions for Peace International. 2020. Available online: https://rfp.org/about/leadership/worldcouncil-2/ (accessed on 25 February 2020).

(C) 2020 by the author. Licensee MDPI, Basel, Switzerland. This article is an open access article distributed under the terms and conditions of the Creative Commons Attribution (CC BY) license (http://creativecommons.org/licenses/by/4.0/). 